\title{
XRD and SEM Studies of Archaeological Stove Tile Ceramics of Turaida Castle
}

\author{
Jana Vecstaudža ${ }^{1}$, Dmitrijs Jakovl̦evs² ${ }^{2}$ Līga Bērzin̦a-Cimdiṇa ${ }^{3},{ }^{1-3}$ Riga Technical University, Vija Stikāne ${ }^{4}$, \\ ${ }^{4}$ Turaida Museum Reserve
}

\begin{abstract}
Stove tile ceramics from Turaida archaeological site were characterized for their mineral and chemical composition. Mineral characteristics of ancient ceramics were determined with $\mathrm{X}$-ray diffractometer. Chemical composition and micromorphology of ceramics and glazes were determined with scanning electron microscope (SEM) with energy dispersive $\mathrm{X}$ ray spectrometer (EDS) unit. The conducted analyzes showed similarity with Latvian clay, suggesting that these stove tiles ceramics are of local origin and production.
\end{abstract}

Keywords: archaeological ceramics, stove tiles, XRD, SEM.

\section{INTRODUCTION}

Ancient Turaida castle is one of the most important and unique archaeological sites in Latvia. In the second half of the $20^{\text {th }}$ century important archaeological excavations in Turaida were done, which were led by $\bar{A}$. Stubavs, R. Malvess and by professor J. Graudonis. During many years of excavations under the guidance of prof. J. Graudonis (1913-2005) more than 7500 stove tiles and their fragments were found. This is one of the largest collections in Latvia of its kind [1].

Despite the interest of historians and archaeologists in Turaida castle history, there has not been conducted a detailed and systematic study dealing with chemical and mineral composition of Turaida archaeological ceramics, especially in the field of stove tile ceramics.

The aim of this study is to investigate the chemical and mineral composition of the archaeological stove tile fragments excavated in Turaida.
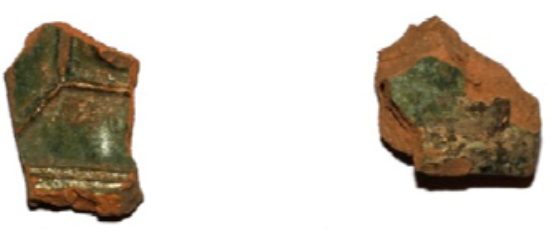

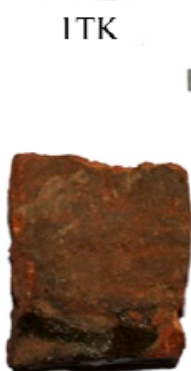

3TK
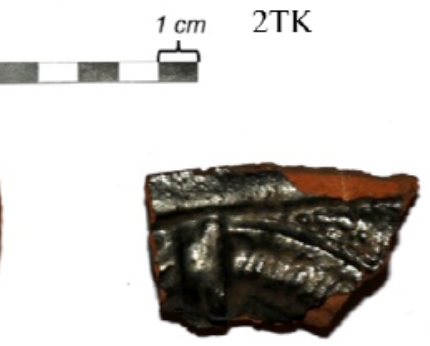

4TK
Fig. 1. The photographs of investigated stove tile fragments.
Studies of this kind give an opportunity to determine ceramics provenance. The provenance of ceramic material includes information about used raw materials and manufacturing technology (firing temperature and firing atmosphere). This knowledge gives a more detailed idea about pottery production, artistic choices and it also eases conservation and restoration of stoves [2,3]. Moreover, such data helps to interpret the social, political, economic and culture contexts and evolution of ancient societies. It reveals interactions between different regions, mainly trade pathways, and the technological evolution of societies $[3,4]$.

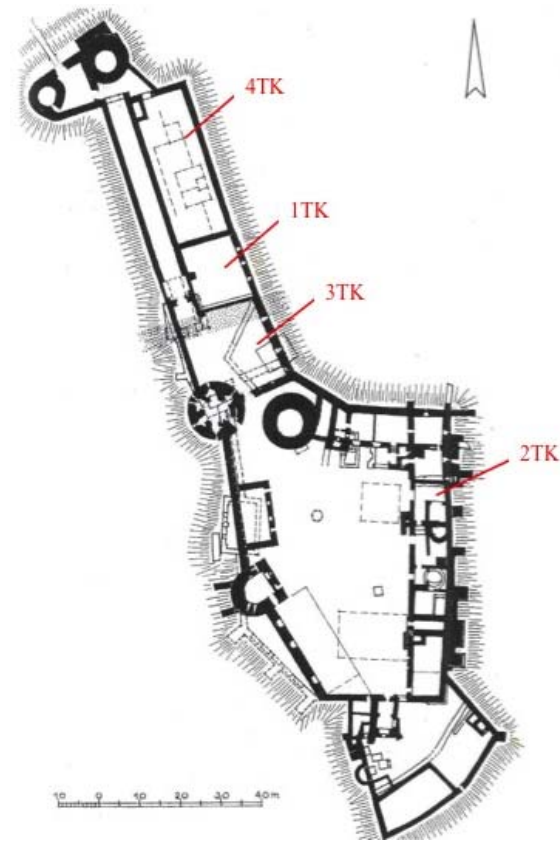

Fig. 2. Map of the Turaida castle territory [5]; sample locations are marked.

Some general observations made during early stage of this research has been already published in popular-science literature [1]. In the present work, we report and thoroughly discuss the experimental results obtained through XRD, SEM and SEM-EDS measurements performed on a set of four fragments of stove tile ceramics found during archaeological excavations in Turaida.

\section{MATERIALS AND METHODS}

\section{A. Samples}

Four different fragments of stove tile ceramics were selected for the analytical study. The respective photographs of glazed stove tile fragments analyzed in this work are shown in Fig. 1. The sites of locations, where the analyzed samples 
were found during archaeological excavations, are shown on Fig. 2. The sample selection criteria for the study were: color of the glaze, partial existence of ornament and the location of astove tile fragment on the castle territory. These criteria indirectly showed, that each one of the selected samples belong to a different stove, each of them was built at another period of time.

All stove tile fragments were found in the debris layer; therefore archaeological dating (relative dating based on finding place and cultural layer horizon) was not applicable. That is why the age of the stove tile fragments was evaluated by their visual appearance - characteristic ornaments and colors of different art styles were linked to manufacturing time. All analyzed stove tile fragments might have been produced from the beginning of 16th century, when stoves with tiles were used for heating purposes, till the fire in 1776, when the castle became uninhabitable.

The visual evaluation of fragments shows that glazes are in a satisfactory condition and glaze adhesion to ceramics is still very good. It shows, that craftsmen of that time matched glaze properties to ceramic ones. The color of the fragments is mainly reddish or brown. A short description of each sample is given here:

- $1 \mathrm{TK}$ - a stove tile fragment with green glaze; the ornament is partially present. Found at the fifth excavation area in the northern forepart of the castle.

- $2 \mathrm{TK}$ - a stove tile fragment with polychrome glaze (traces of yellow and green glaze). Found at the eleventh excavation area.

- $3 \mathrm{TK}$ - a stove tile fragment with a small piece of olive green glaze. Found at the debris layer near the redoubt.

- 4TK - a stove tile fragment with dark brown glaze; the ornament is partially present. Found at the second excavation area in the northern forepart of the castle.

For the information on the production area and technology of the examined stove tile fragments, the samples were studied by means of an integrated analytical approach, including mineralogical, chemical and morphological investigations.

\section{B. Determination of mineral composition}

Mineral analysis of clay-rich ceramics is a widely used tool for the approximate determination of firing temperatures and provenance. The explanation for the previous statement is that specific phases form or disappear in certain well known intervals of temperatures, while the evidence of provenace may be achieved by comparing mineral and chemical composition of raw materials and archaelogical findings [6,7].

Mineralogical characterization of the stove tile ceramics was carried out by X-ray diffraction (XRD) analysis on a X'Pert PRO diffractometer (PANalytical, the Netherlands) with $\mathrm{X}^{\prime}$ Celerator detector. X-Ray tube was equipped with $\mathrm{Cu}$ anode $\left(\mathrm{K} \alpha_{1}=1,540598 \AA\right)$ and Ni filter; voltage was set to $40 \mathrm{kV}$ and current to $30 \mathrm{~mA}$. Diffraction patterns were taken in the range $5,00^{\circ}-53,98^{\circ} 2 \theta$. Crystalline phase identification was performed with computer program X'Pert Highscore coupled with International Centre of Diffraction Data (ICDD) database PDF2/2005.

The small fragments of stove tile potsherds without glaze were thoroughly hand grounded to fine powder in agate mortar. The samples were loaded in a sample holder in a randomly orientated way to minimize preferred orientations of clay minerals.

\section{Determination of chemical composition and morphology}

The chemical composition of glazed stove tile ceramics was determined by the use of scanning electron microscope (SEM) Mira/LMU (Tescan, Czech Republic) equipped with energy dispersive X-ray spectrometer (EDS) unit.

SEM combined with EDS has found many applications to problems of archaeological ceramics. For example, Rathossi [8] and Issi [9] successfully used SEM-EDS analytical technique for the determination of chemical composition of ancient ceramic wares. EDS spectrometers provide a quick determination of the element composition of the sample. The usefulness of EDS method in studies of archaeological ceramics is covered in detail in Froh [10] paper.

Small pieces (dimensions only few millimeters) of potsherd and glaze were cut with pincers. Clay ceramics and glaze are electrically non-conducting, therefore a coating of gold ( $\sim 15 \mathrm{~nm}$ thick) had to be applied by using sputter coater.

The freshly fractured potsherd surfaces were examined, because chemical compositions of external sides of the sample might have undergone unknown changes. While in the case of glazes the external side of the sample coated with gold was analyzed. 5 EDS spectra of each potsherd and glaze sample were taken.

Micro-morphological analyses by SEM of the freshly fractured surfaces coated with gold of all glazed stove tile fragments were performed for detailed study of groundmass microstructure. Combination of scanning electron (SE) and backscattered electron (BSE) detectors were used for microphotograph acquisition.

\section{RESULTS AND DISCUSSION}

\section{A. Mineral composition}

In Fig. 3. X-Ray diffraction patterns with identified crystalline phases of analyzed stove tile ceramics are shown. Crystalline phases present in samples with corresponding ICDD PDF2/2005 database card numbers given in parenthesis were: quartz (00-046-1045), illite (00-026-0911) and Kfeldspars $\mathrm{KAlSi}_{3} \mathrm{O}_{8}$ - microcline or orthoclase (01-089-8572).

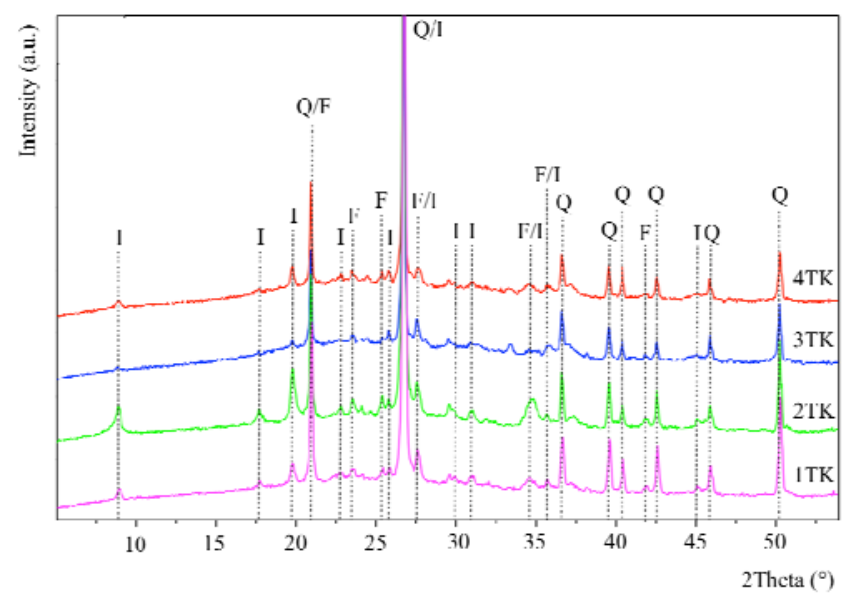

Fig. 3. X-Ray diffraction patterns of Turaida stove tile ceramics. Abbreviations: I - illite, Q - quartz, F - feldspars (microcline or orthoclase). 
TABLE 1

CHEMICAL COMPOSITION OF TURAIDA STOVE TILE CERAMICS (IN WT\%)

\begin{tabular}{|l|l|l|l|l|l|l|l|l|}
\hline & $\mathrm{SiO}_{2}$ & $\mathrm{Al}_{2} \mathrm{O}_{3}$ & $\mathrm{Na}_{2} \mathrm{O}$ & $\mathrm{K}_{2} \mathrm{O}$ & $\mathrm{MgO}$ & $\mathrm{CaO}$ & $\mathrm{Fe}_{2} \mathrm{O}_{3}$ & $\mathrm{TiO}_{2}$ \\
\hline $1 \mathrm{TK}$ & 62,19 & 20,79 & 0,28 & 6,61 & 2,19 & 0,74 & 6,04 & 1,16 \\
\hline $2 \mathrm{TK}$ & 61,99 & 21,14 & 0,10 & 6,30 & 2,50 & 0,93 & 6,02 & 1,01 \\
\hline $3 \mathrm{TK}$ & 57,46 & 22,63 & 0,44 & 7,58 & 2,83 & 0,79 & 7,28 & 0,98 \\
\hline $4 \mathrm{TK}$ & 55,95 & 23,41 & 0,24 & 7,72 & 2,62 & 0,86 & 8,00 & 1,20 \\
\hline
\end{tabular}

The mineral composition of all samples is uniform: the samples contain previously mentioned minerals in slightly various amounts and the main mineral present in all samples is quartz.

It should be emphasized, that sample 3TK contains trace amounts of clay mineral illite. The last statement indicates that 3TK stove tile was fired in higher temperature than other analyzed tiles. The firing temperature of 3TK ceramics may be closer to $900^{\circ} \mathrm{C}$, than that of $1 \mathrm{TK}, 2 \mathrm{TK}$ and $4 \mathrm{TK}$. Also during the sample preparation for XRD analysis more effort was needed to ground 3TK ceramics, this correlates with the information gained from XRD analysis.

The arrangement of the samples according to relative intensity of characteristic illite diffraction peak at $8,82^{\circ} 2$ Theta in decreasing order gives a following row: $2 \mathrm{TK}>1 \mathrm{TK}>4 \mathrm{TK}>$ 3TK. The descending amount of illite may indicate the increase of firing temperature (decomposition temperature of illite $\left.825-900^{\circ} \mathrm{C}[11,12]\right)$. This assumption may be true if raw materials for all analyzed samples were taken from one site. However, it may be misleading information if they are taken form different deposits. The arrangement of the samples according to relative intensities of feldspars diffraction peak at $27,53^{\circ}$ 2Theta in decreasing order gives another row: $2 \mathrm{TK}>1 \mathrm{TK}>3 \mathrm{TK}>4 \mathrm{TK}$. The determination of approximate firing temperatures based on relative intensities of illite or feldspars diffraction peaks practically is not possible, because the initial amount of illite or feldspars in raw materials is unknown. Also heterogeneity, age and size of the samples must me taken into account and as non-destructive approach as possible should be used in the analysis of the archaeological materials [3]. The authors of this paper assume that disappearance of illite diffraction peak is a much more straightforward indicator of approximate firing temperature interval than the most intense diffraction peak of feldspars.

There are some detailed papers [12,13] about firing temperature determination based on approximate amounts of carbonates implicated in ceramic material. Unfortunately the analyzed samples probably contain only trace amounts of carbonates and this method cannot be used in the current research. Later the statement is supported by the presence of illite peak in X-Ray diffraction patterns, because decomposition of calcite begins at $650-750^{\circ} \mathrm{C}$ and ends at 800 $900^{\circ} \mathrm{C}$ [13]. Basically decomposition of illite and calcite are simultaneous and ends up at the same temperature. It means that if illite is still present calcite should be present too. Also calcium bearing phases (e.g., gehlenite, wollastonite or anorthite) were not found during the mineralogical analysis.

\section{B. Chemical composition of stove tile ceramics}

The concentrations of the major components in stove tile potsherds obtained by SEM-EDS analysis are listed in Table 1. Five repeated measurements were conducted on each sample; only average values are presented.

The chemical composition of all analyzed samples qualitatively and quantitatively is similar. The main constituents of stove tile potsherds are $\mathrm{SiO}_{2}$ and $\mathrm{Al}_{2} \mathrm{O}_{3}$ - they indicate the presence of quartz and various aluminosilicates (e.g., clay minerals, feldspars and other). Comparatively high $\mathrm{K}_{2} \mathrm{O}$ content is attributed to the presence of potassium ions in clay mineral illite and other minerals, for example, microcline. In our case most of $\mathrm{K}_{2} \mathrm{O}$ can be subjected to illite - the most common clay mineral on the territory of Latvia $[14,15]$. Small amounts of $\mathrm{CaO}$ and $\mathrm{MgO}$ may be attributed to $\mathrm{Ca} / \mathrm{Mg}$ carbonates, silicates or other compounds. In most cases $\mathrm{CaO}$ is mainly ascribed to calcium carbonate. The clay deposits near Turaida are from Devonian period $(\mathrm{CaO}=0,70-3,29 \%)$ and contrary to Quaternary period $(\mathrm{CaO}=4,02-17,65 \%)$ contain carbonates in smaller amounts [15]. It means that ancient potters may have used practically non-calcerous clay for stove tile manufacturing nearby Turaida.

\section{Chemical composition of glazes and potsherd-glaze transition zone}

By the use of SEM-EDS method chemical compositions of green, dark brown and yellow glazes were determined in several points across potsherd-glaze transition zone. An example of the point location in the case of green glaze (sample 2TK) is shown in Fig. 4. The chosen glaze region for SEM-EDS analysis represents a uniform surface and composition.

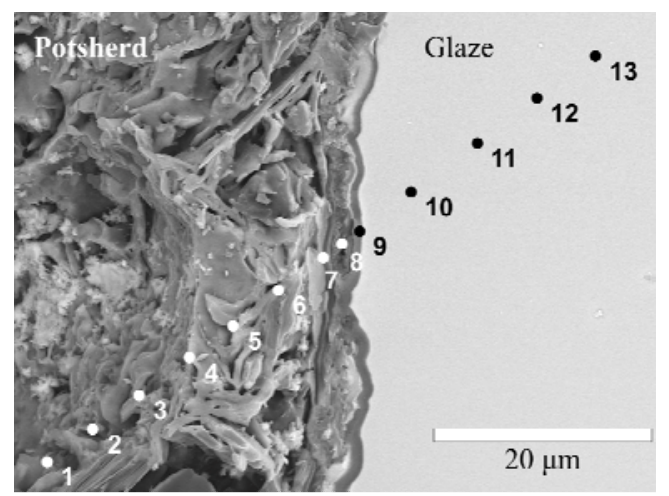

Fig. 4. Example of point location on the 2TK sample (applied SEM-EDS measurement principle) [1]. 
(a)

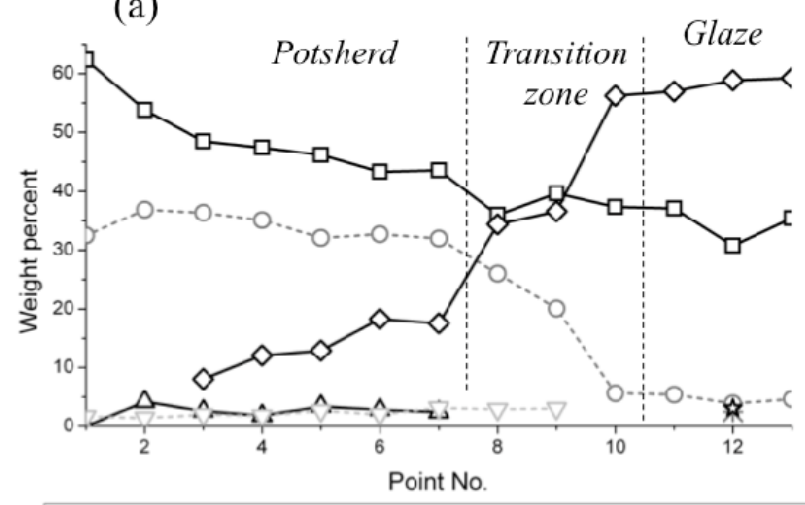

$-\square-\mathrm{SiO}_{2}-\mathrm{O}-\mathrm{Al}_{2} \mathrm{O}_{3}-\triangle-\mathrm{Fe}_{2} \mathrm{O}_{3}-\nabla-\mathrm{K}_{2} \mathrm{O} \prec-\mathrm{PbO} \rightarrow-\mathrm{SnO}_{2} \rightarrow-\mathrm{Sb}_{2} \mathrm{O}_{3}$

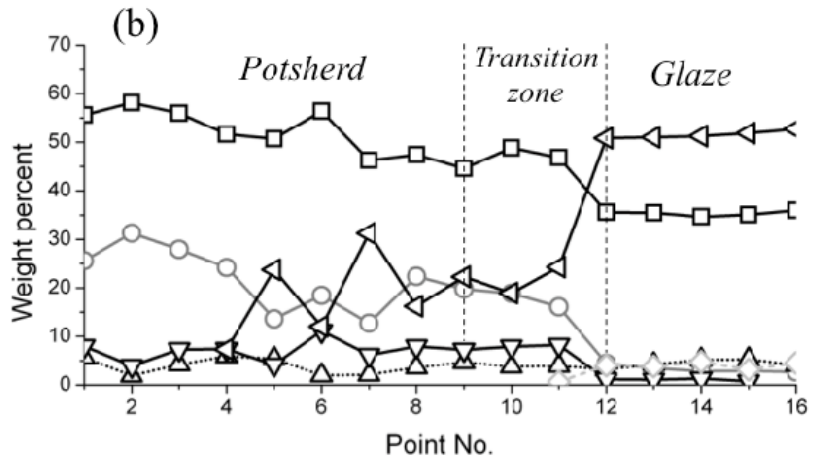

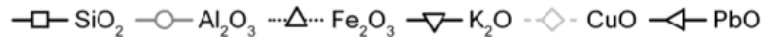

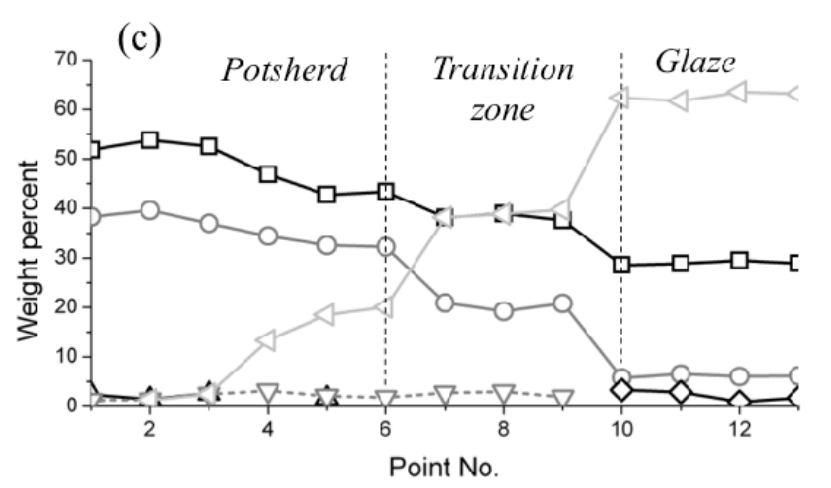

$\neg-\mathrm{SiO}_{2}-\mathrm{O}-\mathrm{Al}_{2} \mathrm{O}_{3}-\triangle-\mathrm{Fe}_{2} \mathrm{O}_{3} \cdot \nabla \cdot-\mathrm{K}_{2} \mathrm{O} \prec-\mathrm{CuO} \smile-\mathrm{PbO}$

Fig. 5. Chemical composition of stove tile ceramic, ceramic-glaze transition zone and glazes: (a) yellow, (b) dark brown and (c) green.

Chemical compositions of the analyzed glazes are shown in Fig. 5. All these glazes contained lead and silicon oxides, it means glazes were prepared form lead silicate glass. From the graphs it can be seen that the amount of $\mathrm{PbO}$ increases while the amount of $\mathrm{SiO}_{2}$ and $\mathrm{Al}_{2} \mathrm{O}_{3}$ decreases. Such changes in the chemical composition clearly show, where potsherd part, glaze and potsherd-glaze transition zone are. $\mathrm{Fe}_{2} \mathrm{O}_{3}$ and $\mathrm{K}_{2} \mathrm{O}$ are still present in the transition zone, but only in a smaller amount.

Green glaze (Fig. 5. c), without previously mentioned $\mathrm{SiO}_{2}$, $\mathrm{Al}_{2} \mathrm{O}_{3}$ and $\mathrm{PbO}$, contains $\mathrm{CuO}$. It means that copper compounds were used as green glaze coloring agents (e.g., $\mathrm{CuCO}_{3}, \mathrm{CuSO}_{4}$ or $\mathrm{CuO}$ ). Lead, tin and antimony compounds colored yellow glaze, whereas iron and copper compounds colored dark brown glaze. Element assignment as coloring agents was done on the basis of literature data $[16,17]$.

\section{Microstructure}

In the microphotograph (Fig. 6) stove tile potsherd part, glaze and transition zone between both - glaze and potsherd is shown. The transition zone is clearly distinguishable. Microstructure of potsherd is textured, streaky and porous. Streaky microstructure of stove tile potsherd is formed because of platelet like clay particle orientation [18]. No substantial differences between the four ceramic samples were revealed, and they all showed similar textural and compositional features.

Scanning electron microscopy helps to evaluate the glaze uniformity and defects, e.g., cracks and air bubbles. In the glaze a trapped air bubble can be seen in Fig. 6B. The microstructure of all analyzed stove tile glazes is dense and glassy. Glaze and potsherd have a tight chemical linkage. On the potsherd and glaze boundary distinct crystalline transition zone can be seen (fracture plane); its width is from few $\mu \mathrm{m}$ till $\sim 50 \mu \mathrm{m}$.

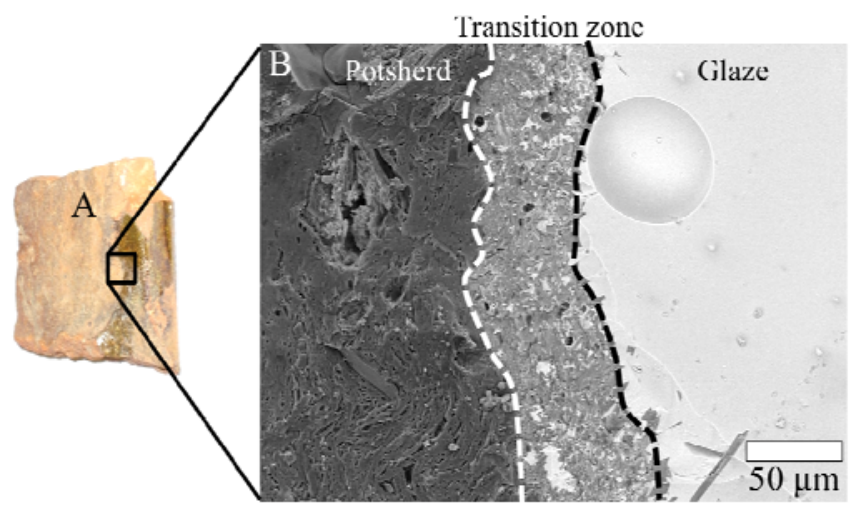

Fig. 6. Photograph (A) and microphotograph (B) of 3TK sample [1].

\section{CONCLUSIONS}

A set of four stove tile fragments, coming from archaeological excavation in Turaida, was investigated by XRD, SEM and SEM-EDS measurements.

Experimental results of chemical analysis showed that stove tile potsherds are mainly composed of $\mathrm{SiO}_{2}, \mathrm{Al}_{2} \mathrm{O}_{3}, \mathrm{~K}_{2} \mathrm{O}$ and $\mathrm{Fe}_{2} \mathrm{O}_{3}$. Small amounts of $\mathrm{Na}_{2} \mathrm{O}, \mathrm{MgO}$ and $\mathrm{CaO}$ are also present. Chemical composition of all analyzed stove tile fragments was similar - both qualitatively and quantitatively.

All analyzed stove tile potsherds were composed of illite, quartz and feldspars in slightly different proportions.The presence of illite diffraction peaks shows, that stove tiles were fired below $900^{\circ} \mathrm{C}$.

The results of chemical and mineral analysis lead us to the conclusion, that all these stove tiles might have been manufactured from the local Devonian clay with a low carbonate content.

The stove tiles were glazed with lead silicate glazes. As coloring agents were used copper compounds for green glaze; lead, tin and antimony compounds for yellow glaze and iron and copper compounds for dark brown glaze. 
In summary it can be stated that the analyzed stove tile fragments were probably locally produced, because their chemical and mineral composition resembles that of the local clay sediments, also microstructural features of all analyzed samples were similar. This hypothesis is only confined to a small number of stove tile fragments and needs to be further tested and verified on a larger number of samples.

Future work will include investigations of composition and ceramic properties of raw materials from local sites near Turaida castle. The authors plan to test the developed analytical approaches on other archaeological ceramic materials as well.

\section{ACKNOWLEDGMENTS}

Authors of the article are grateful for the funding granted by Latvian government within National Research Program "Sustainable use of local resources (underground resources, wood, food and transport) - new products and technologies (NatRes)", V7904.

\section{REFERENCES}

[1] Ose, I. Turaidas pils 16.-18. gadsimta krāsns keramika. Rīga: Latvijas vēstures institūta apgāids, 2013.

[2] Akyuz, S., Akyuz, T., Basaran S. et.al. Analysis of ancient potteries using FT-IR, micro-Raman and EDXRF spectrometry. Vibrational Spectroscopy, 2008, 48, N 2, pp. 276-280. http://dx.doi.org/10.1016/j.vibspec.2008.02.011

[3] Barone, G., Crupi, V., Longo, F. et.al. Characterisation of archaeological pottery: The case of 'Ionian Cups'. Journal of Molecular Structure, 2011, 993, N 1-3, pp. 142-146. http://dx.doi.org/10.1016/j.molstruc.2011.01.028

[4] Bertolino, S. Provenance and ceramic technology of pot sherds from ancient Andean cultures at the Ambato valley, Argentina. Applied Clay Science, 2003, 24, N 1-2, pp. 21-34. http://dx.doi.org/10.1016/j.clay.2003.03.001

[5] Jansons, A. Turaidas pils arhitektūra. 13.-17. gadsimts. Rīga: Latvijas vēstures institūta apgāds, 2007.

[6] Barone, G., Crupi, V., Longo, F. et.al. FT-IR spectroscopic analysis to study the firing processes of prehistoric ceramics. Journal of Molecular Structure, 2011, 993, N 1-3, pp. 147-150. http://dx.doi.org/10.1016/j.molstruc.2010.12.018

[7] Damjanović, L., Holclajtner-Antunović, I., Mioč, U. B. et.al. Archaeometric study of medieval pottery excavated at Stari (Old) Ras, Serbia. Journal of Archaeological Science, 2011, 38, N 4, pp. 818-828. http://dx.doi.org/10.1016/j.jas.2010.11.004

[8] Rathossi, C., Tsolis-Katagas, P., Katagas, C. Technology and composition of Roman pottery in northwestern Peloponnese, Greece. Applied Clay Science, 2004, 24, N 3-4, pp. 313-326. http://dx.doi.org/10.1016/j.clay.2003.07.008

[9] İssi, A., Raškovska, A., Kara, A. et.al. Scanning electron microscopy and micro-Raman spectroscopy of slip layers of Hellenistic ceramic wares from Dorylaion/Turkey. Ceramics International, 2011, 37, N 6, pp. 1879-1887. http://dx.doi.org/10.1016/j.ceramint.2011.02.013

[10] Froh, J. Archaeological Ceramics Studied by Scanning Electron Microscopy. Hyperfine Interactions, 2004, 154, N 1-4, pp. 159-176. http://dx.doi.org/10.1023/B:HYPE.0000032074.98045.cc

[11] Maritan, L., Nodari, L., Mazzoli, C. et.al. Influence of firing conditions on ceramic products: experimental study on clay rich in organic matter. Applied Clay Science, 2006, 31, pp. 1-15. http://dx.doi.org/10.1016/j.clay.2005.08.007

[12] Cultrone, G., Rodriguez-Navarro, C., Sebastian, E. et.al. Carbonate and silicate phase reactions during ceramic firing. European Journal of Mineralogy, 2001, 13, N 3, pp. 621-634. http://dx.doi.org/10.1127/09351221/2001/0013-0621

[13] Tschegg, C., Ntaflos, T., Hein, T. Thermally triggered two-stage reaction of carbonates and clay during ceramic firing - A case study on Bronze Age Cypriot ceramics. Applied Clay Science, 2009, 43, N 1, pp. 69-78. http://dx.doi.org/10.1016/j.clay.2008.07.029

[14] Seglinšs, V., Sedmale, G., Vircava, I. Latvijas minerālās izejvielas: īpašību apkopojums. RTU zin. rakstu krāj. Materiālzinātne un lietišksā ǩimija, 2011, 24, pp. 116-135.

[15] Segliňš, V., Stinkule, A., Stinkulis, G. Derīgie izrakteṇi Latvijā. Rīga, LU Akadēmiskais apgāds, 2013.

[16] Peterson, S., Peterson, J. The Craft and Art of Clay: A Complete Potter's Handbook. Laurence King Publishing, 2003.

[17] Cooper, E. The Potter's Book of Glaze Recipes. University of Pennsylvania Press, 2004.

[18] Bergaya, F., B. Theng, B.K., Lagaly, G. Handbook of Clay Science. Elsevier Science, 2006

Jana Vecstaudža (Bsc. ing. 2012) currently is a second-year Master Student in Chemical Engineering at Riga Technical University. She works as a Research Assistant at the Institute of General Chemical Engineering, RTU (since 2011). J. Vecstaudža is a member of the Latvian Materials Research Society (since 2013) and a member of the Association of Latvian Young Scientists (since 2012). Her scientific interests include identification and analysis of clay and clay minerals, synthesis of glass ceramics.

Address: Āzenes street 14/24, Riga, Latvia, LV-1084

E-mail: jana.vecstaudza@rtu.lv

web-page: https://ortus.rtu.lv/science/lv/experts/11273

Dmitrijs Jakovḷevs received his BSc and MSc degrees in Chemical Engineering from Riga Technical University, Latvia. In 2010 he joined Riga Biomaterial Innovation and Development Center of RTU as a Researcher. He is currently a Doctoral Student at the Department of General Chemical Engineering at Riga Technical University. His research interests include biomaterial microstructures, biocompatible coatings and medical materials science. Additionally, D. Jakovḷevs is a specialist in SEM/TEM/EDX/FIB/GIS

Address: Āzenes street 14/24, Riga, Latvia, LV-1084

E-mail: dmitrijs.jakovlevs@inbox.lv

Lìga Bērzinna-Cimdiña (Dr. sc. ing. 1989) currently is the Head of the Institute of General Chemical Engineering (since 2010); Professor (since 2009) and the Head of the Department of General Chemical Engineering (since 2006). Prof. L. Bērzinna-Cimdina is a member of the Latvian Materials Research Society (since 1994); a member of ECERS journal "Journal of the European Ceramic Society" editorial board (since 1996); a member of European Biomaterials Society (since 2000).

Address: Pulka street 3/3, Riga, Latvia, LV-1054

E-mail: liga.berzina-cimdina@rtu.lv

web-page: http://rbiac.rtu.lv/

Vija Stikāne (Dr. hist. 2012) works as the Head of Collection and Exhibition Department of the Specially Protected Cultural MonumentTuraida Museum Reserve. Scientific interests of Vija Stikāne include history of Turaida (Treyden) castle; social history of the Medieval and Early Modern Livonia (13th-16th century).

Address: Turaida Street 10, Sigulda, LV-2150, Latvia

E-mail: petnieciba.tmr@apollo.lv

web-page: http://www.turaida-muzejs.lv/

\section{Jana Vecstaudža, Dmitrijs Jakoṿ̣evs, Līga Bērziņa-Cimdiṇa, Vija Stikāne. Turaidas pils arheoloğiskās krāšṇu keramikas XRD un SEM pētījumi}

Senā Turaidas pils ir viens no nozīmīgākajiem arheologiskajiem pieminekḷiem Latvijā. Neskatoties uz pastiprinātu vēsturnieku un arheologu interesi par Turaidas vēsturi, līdz šim sistemātiski un detalizēti ķīmiskā un minerālā sastāva pētījumi nav veikti, it īpaši krāšņu keramikas jomā. Pētījuma mērḳis ir noteikt Turaidas krāsns keramikas izcelsmi - lietotos izejmateriālus un apdedzināšanas temperatūru, balstoties uz ķīmiskās un minerālās analīzes metodēs gūtiem novērojumiem. 
Arheoloǵiskos izrakumos iegūtās četras krāsns podinu lauskas analizētas ar XRD, SEM un SEM-EDS metodēm. Ar XRD palīdzību noteikts senās keramikas minerālais sastāvs, ar SEM - keramikas un glazūras mikrostruktūra, savukārt ar SEM-EDS - keramikas drumstalas un glazūru kīmiskais sastāvs.

Ar k̦īmiskās analīzes palīdzību noteikts, ka analizētā krāsns keramikas drumstala pārsvarā sastāv no $\operatorname{SiO}_{2}, \mathrm{Al}_{2} \mathrm{O}_{3}, \mathrm{~K}_{2} \mathrm{O}$ un $\mathrm{Fe}_{2} \mathrm{O}_{3}$, nelielos daudzumos konstatēti arī $\mathrm{Na}_{2} \mathrm{O}, \mathrm{MgO}$ un $\mathrm{CaO}$. Visu analizēto krāsns podinuu lausku ķīmiskais sastāvs ir viendabīgs - gan kvalitatīvi, gan kvantitatīvi.

Veicot XRD analīzi, keramikas sastāvā konstatēts illīts, kvarcs un laukšpati nedaudz atšķirīgās proporcijās. Illīta difrakcijas pīķu esamība norāda, ka krāsns podiṇi apdedzināti temperatūrā, kas zemāka par $900^{\circ} \mathrm{C}$.

Krāsns podiṇu glazēšanai lietotas svina silikātu saturošas glazūras. Vara savienojumi lietoti zaḷās glazūras iegūšanai, svina, alvas un antimona savienojumi dzeltenās glazūras iekrāsošanai, savukārt dzelzs un vara savienojumi tumši brūnās glazūras iegūšanai.

Apkopojot iegūtos rezultātus var secināt, ka Turaidas pil̄̄s lietotie krāsns podiṇi, iespējams, veidoti no vietējas izcelsmes izejvielām. To apliecina analīzēs iegūto k̦īmisko un minerālo sastāvu līdzība ar Latvijas māliem. Kā arī keramikas mikrostruktūra visiem analizētajiem paraugiem ir ḷoti līdzīga. Šì hipotēze, protams, pārbaudīta uz nelielu skaitu paraugu, tāpēe turpmākajā darbā jāiekḷauj vairāk paraugu, lai gūtu piln̄̄gāku hipotēzes apstiprinājumu.

Яна Вецстауджа, Дмитрий Яковлев, Лига Берзиня-Цимдиня, Вия Стикане. РДА и СЭМ исследование археологической печной керамики Турайдского замка.

Древний Турайдский замок - один из важнейших и уникальных археологических памятников Латвии. Несмотря на большой интерес историков и археологов к истории Турайдского замка, подробные и систематичные исследование химического и минерального состава не реализованы, по крайней мере в области печной керамики. Цель этого исследования выяснять химический и минеральный состав археологических фрагментов печных кафелей и узнать их происхождение - исходные материалы и температуру обжига.

Четыре фрагмента печной кафели были исследованы методами РДА, СЭМ и СЭМ-ЭДС. РДА использовали для определения минерального состава древней керамики. Микроструктура керамической части и глазурей печной кафели и определялась методом СЭМ. С помощью СЭМ-ЭДС определен химический состав керамики и глазурей.

Химический анализ показал, что печной кафель по большей части состоит из $\mathrm{SiO}_{2}, \mathrm{Al}_{2} \mathrm{O}_{3}, \mathrm{~K}_{2} \mathrm{O}$ и $\mathrm{Fe}_{2} \mathrm{O}_{3} . \mathrm{Na}_{2} \mathrm{O}, \mathrm{MgO}$ и СаO присутствуют в небольших количествах. Химический состав анализированного печного кафеля похож - качественно и количественно. Все анализированные керамические фрагменты кафели состояли из иллита, кварца и полевых шпатов в несколько иных пропорциях. Присутствие дифракционных пиков иллита показывает, что температура обжига печного кафеля была ниже $900^{\circ}$ С. Древний печной кафель глазурован глазурей свинцово силиката. Зелёная глазурь сделана добавляя соединения содержащие медь; жёлтый соединения содержащие свинец, олово и сурьму; тёмно коричневый - соединения содержащие железо и медь.

В заключение можно утверждать, что анализированные фрагменты печного кафеля, возможно, были сделаны в Турайде, потому что их химический и минеральный состав примерно соответствует латвийской глине. К тому же микроструктуры образцов были похожи. Эта гипотеза ограничивается небольшим количеством фрагментов печной кафели, поэтому необходимо дальнейшее тестирование и проверка на большем количестве образцов. 